\title{
RANCANG BANGUN INDIKATOR BERAT, TEMPERATUR DAN KADAR ALKOHOL PADA PROSES FERMENTASI SINGKONG (TAPE) DENGAN METODE FUZZY BERBASIS MICROCONTROLLER ATMEGA 16
}

\author{
${ }^{1}$ Nurul Isnainin, ${ }^{2}$ Miftachul Ulum, ${ }^{3}$ Koko Joni. \\ 1,2,3 Program Studi Teknik Elektro, Fakultas Teknik, Universitas Trunojoyo Madura \\ nurulisnainin495@gmail.com, miftachul.ulum@trunojoyo.ac.id , kokojoni@trunojoyo.ac.id
}

\begin{abstract}
Abstrak
Pada umumnya, dalam pembuatan tape para produsen tape masih menggunakan cara manual sehingga kualitas tape sering mengalami prubahan hal ini disebabkan karena ada beberapa faktor yaitu kondisi suhu, ragi yang dibutuhkan serta kadar alkohol yang terkandung dalam tape untuk menentukan tingkat kematangan tape. Permasalahan yang dialami produsen tape dapat dilakukan suatu pengendalian rancang bangun sistem dalam proses fermentasi dengan menggunakan 3 buah sensor. Metode yang di gunakan dalam penelitian ini adalah metode fuzzy tsukamoto. Penelitian skripsi ini bertujuan proses fermentasi dapat di lakukan secara otomatis dengan merancang bangun suatu sistem kendali pengontrol suhu, kadar alkohol dan persbandingan ragi yang di gunakan. Pengontrolan sistem alat ini dilakukan oleh mikrokontroler ATMega 16 mempunyai 3 input berbentuk sensor DHT11, sensor MQ3 dan input berbentuk sensor load cell, sensor DHT11 ini akan mendeteksi suhu, sedangkan sensor load cell mendeteksi berat singkong yang berada dalam inkubator dan ditampilkan pada LCD dan untuk sensor MQ-3 dapat menentukan kematangan tape. Hasil penelitian ini menunjukan bahwa ragi yang baik untuk digunakan fermentasi adalah 4 gram persatu kilogram singkong. Hasil rancang bangun alat ini lebih efisien $58.29 \%$ dari pada fermentasi secara manual.

Kata kunci : Fermentasi Tape, Microcontroller, Fuzzy Tsukamoto, Loadcell, DHT11, MQ-3
\end{abstract}

\section{Abstract}

In general, in making tape, tape producers still use manual method so that the quality of the tape often changes because this is due to several factors, namely the temperature conditions, the required yeast and the alcohol content contained in the tape to determine the level of tape maturity. Problems experienced by tape producers can be done by controlling a system design in the fermentation process by using 3 sensors. The method used in this research is the Tsukamoto fuzzy method. This thesis research aims at the fermentation process can be carried out automatically by designing and building a temperature control system, alcohol content and yeast ratio used. The control system of this tool is done by ATmega 16 microcontroller has 3 inputs in the form of DHT11 sensor, MQ-3 sensor and loadcell sensor input, this DHT11 sensor will detect temperature, while loadcell sensor detects the weight of cassava in the incubator and is displayed on the LCD and for sensors MQ-3 can determine tape maturity. The results of this study indicate that good yeast for fermentation is 4 grams $/ \mathrm{kg}$ of cassava. The results of the design of this tool are $58.29 \%$ more efficient than manual fermentation.

Keywords : Fermented Tape, Microcontroller, Fuzzy Tsukamoto, Loadcell, DHT11, MQ-3

\section{Pendahuluan}

Tape merupakan salah satu makanan tradisional yang banyak dinikmati berbagai kalangan. Dalam proses fermentasi tape para produsen tape masih menggunakan cara manual yaitu tape di fermentasi di suatu wadah yang hanya di tutupi oleh kain atau dedaunan. Dengan cara manual tersebut hasil fermentasi sering mengalami kegagalan atau kuaitas tape buruk hal ini terjadi karena proses fermentasi di pengaruhi oleh beberapa faktor yaitu suhu, takaran ragi yang di butuhkan dan kandungan alkohol pada tape yang menentukan tingkat kematangan tape[1]. Seiring dengan perkembangan teknologi dan ilmu pengetahuan bidang elektronika mengalami kemajuan yang begitu pesat sehingga dapat di manfaatkan untuk mempermudah kehidupannya.

Berdasarkan penjelasan tersebut, maka penulis mencoba merancang dan membuat suatu alat fermentasi menggunakan mikrokontroller sebagai pengendali dan arduino sebagai penerima data yang di krimkan oleh mikrokontroller dan disimpan ke SD Card berdasarkan waktu (RTC). Pada alat fermentasi yang di buat terdapat 3 buah sensor yaitu sensor suhu sebagai pengendali suhu, sensor loadcell digunakan sebagai peengatur takaran ragi dan sensor MQ-3 berfungsi sebagai pendeteksi kadar alkohol. Metode yang digunakan adalah metode fuzzy yang di gunakan untuk mengendalikan kondisi suhu dan kandungan 
alkohol untuk menetukan keluaran berupa kipas dan pemanas.

A. Mikrokontroler Atmega16

Mikrokontroler ATMega16 adalah sebuah komputer mini/kecil yang ada di dalam satu IC yang di dalamnya berisi CPU, timer, memori, saluran komuikasi serial dan paralel, port input/output, ADC

B. Seonsor loadcell

alat elektromekanik yang biasa disebut Transducer, yaitu gaya yang bekerja berdasarkan prinsip deformasi sebuah material akibat adanya tegangan mekanis yang bekerja, kemudian merubah gaya mekanik menjadi sinyal listrik.

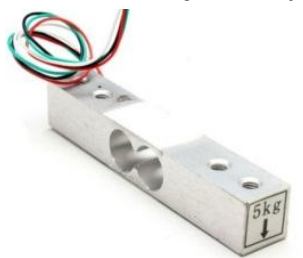

Gambar 1. sensor loadcell

C. Sensor DHT11

Sensor DHT11 adalah modul sensor yang berfungsi untuk mensensing objek suhu dan kelembapan yang memiliki output tegangan analog yang dapat diolah lebih lanjut menggunakan mikrokontroler.

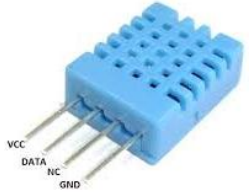

Gambar 2. sensor DHT11

D. Sensor MQ-3

Sensor gas alkohol MQ-3 adalah sensor yang cocok untuk mendeteksi kadar alkohol secara langsung, Driver untuk sensor MQ-3 ini sangat sederhana, hanya memerlukan 1 buah resistor variabel. Output sensor MQ-3 dalam bentuk tegangan analog yang sebanding dengan kadar alkohol yang diterima.

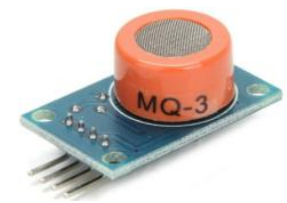

Gambar 3. sensor MQ-3

E. Metode Fuzzy Tsukamoto

Pembentukan fuzzy Tsukamoto adalah : IF (X IS A) and (Y IS B) Then (Z IS C)
Dimana keanggotaan A, B, C merupakan himpunanfuzzy.[2]

Contoh : diketahui 2 buah rule berikut : IF ( $\mathrm{x}$ is $\mathrm{A} 1$ ) AND ( $\mathrm{y}$ is $\mathrm{B} 1$ ) THEN ( $\mathrm{z}$ is $\mathrm{C} 1$ ) IF ( $x$ is $A 2$ ) AND ( $y$ is $B 2$ ) THEN ( $z$ is $C 2$ ) Beberapa tahapan diantaranya metode fuzzy tsukamoto

diantaranya :

1. Fuzzyfikasi

2. Pembentukan basis pengetahuan Fuzzy (Rule dalam bentuk IF...THEN)

3. Mesin inferensi

4. Menggunakan fungsi implikasi MIN untuk mendapatkan nilai $\alpha$-predikat tiap-tiap rule $(\alpha 1$, $\alpha 2, \alpha 3, \ldots . \alpha \mathrm{n})$.

Kemudian masing-masing nilai $\alpha$-predikat ini digunakan untuk menghitung keluaran hasil inferensi secara tegas (crisp) masing-masing rule $(\mathrm{z} 1, \mathrm{z} 2, \mathrm{z} 3, \ldots . \mathrm{zn})$.

Defuzzyfikasi

Menggunakan metode Rata - Rata (Average)

$\mathrm{Z}^{*}=\frac{\sum \alpha i z i}{\sum \alpha \mathrm{i}}$

A. Metode

\section{Metodelogi Penelitian}

Adapun tahapan-tahapan dalam metode penelitian ini dijelaskan sebagai berikut:

a. Studi literatur

Tahapan ini dilakukan studi literatur mengenai alat fermentasi tape.

b. Perancangan sistem

Pada tahap ini dilakukan perancangan alat fermentasi tape yang dilengkapi dengan 3 buah input sensor yaitu DHT11, MQ-3, Loadcell dan 2 outputan berupa kipas dan heater

c. Perakitan komponen

Pada tahap ini dilakukan perakitan terhadap semua komponen yang dibutuhkan untuk merancang sebuah alat fermentasi tape

d. Pengujian komponen alat

Pada tahap ini dilakuan pengujian yaitu kalibrasi semua sensor DHT11, MQ-3, Loadcell dengan alat ukur dan pengujian keseluruhan sistem alat fermentasi tape. Pemgujian ini dilakukan di laboratorium Teknik Elektro Universitas Trunojoyo Madura

B. Perancangan Hardware

Perangkat keras yang digunakan dalam penelitian ini adalah rangkaian pengujian sensor menggunakan Mikrokontroller ATmega16 sekaligus sebagai pengirim data dan Aduino nano sebagai penerima data. 


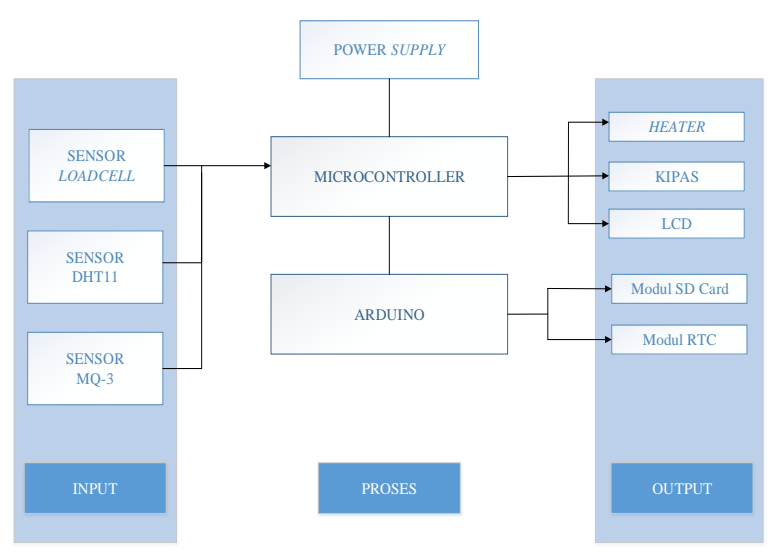

Gambar 4. perancangan Hardware

Dari gambar hardware di atas maka dapat di ketahui proses pertama yang dilakukan yaitu inputan berupa pembacaan 3 buah sensor yang di kontrol oleh mikrokontroller adalah sensor DHT11 sebagai pengendali suhu, MQ3 sebagai pendeteksi kandungan kadar alkohol dan lodcell di gunakan sebagai pengatur ragi yang dibuthkan. Proses selanjutnya dari pembacaan sensor tersebut akan menghasilkan keluaran berupa heater sebagai elemen pemanas, kipas sebagai pendingin dan LCD sebagai tampilan data, data yang dihasilkan sensor akan di kirim mikrokontroller ke arduino sebagai penerima data yang akan di simpan di SD Card berdasarkan waktu.

\section{Algoritma keseluruhan sistem}

Algoritma yang digunakan untuk perangkat lunak di dalam Mikrokontroller ATmega16 dan Arduino memiliki cara kerja yang sama yaitu sebagai kendali dalam sistem kontrol dan instrumentasi. Firmware pada ATMEL AVR ATmega16 di tulis menggunakan bahasa $\mathrm{C}$ dan di kompilai melalui perangkat lunak CodeVisom AVR versi 2.05.perangkat lunak dalam Arduino Nano di program melalui Arduino IDE versi1.0.1 dengan bahasa $\mathrm{C}$.

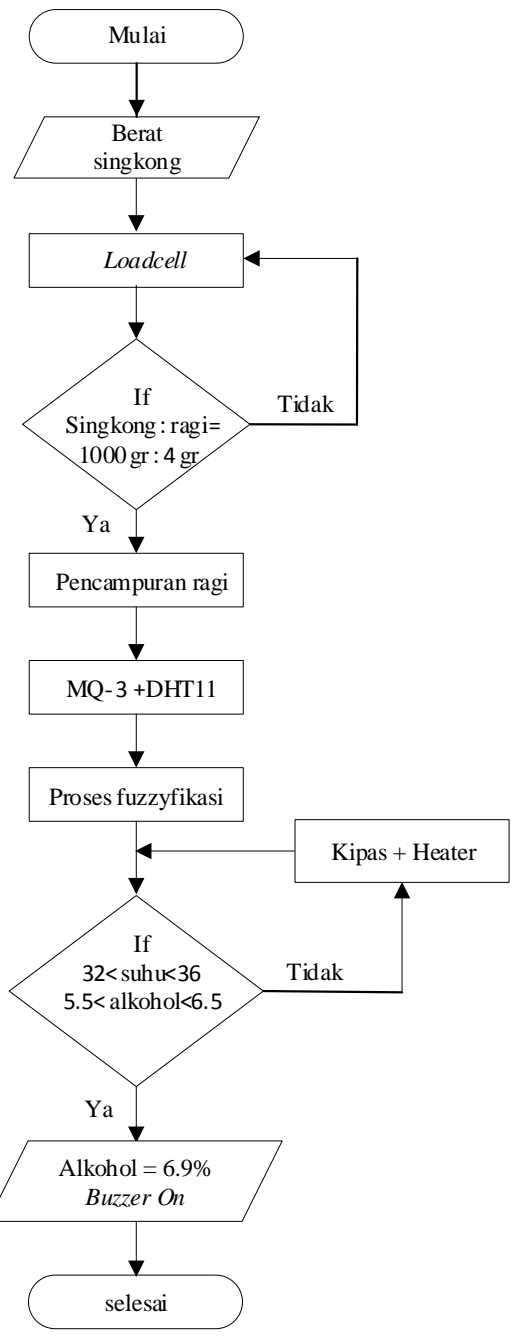

Gambar 5. algoritma keseluruhan sistem

Dari gambar flowchart di atas dapat diketahui untuk memulai sistem langkah awal yaitu menginputkan berat singkong yang akan difermentasi dan diproses oleh sensor loadcell untuk mengetahui ragi yang akan digunakan, setelah ragi dan singkong tercampur selanjutnya sensor DHT11 dan MQ-3 mulai bekerja yang akan diproses oleh metode fuzzy untuk menentukan output berupa heaterdan kipas sesuai dengan kondisi yang dideteksi oleh sensor DHT11 dan MQ-3. Selama proses fermentasi akan terdapat kandungan alkohol ada singkong semakin lama proses fermentasinya maka kandungan alkohol akan semakin meningkan dan apabila kandungan alkohol pada tape sudah mencapai 6,9\% buzzer akan dalam keadaan on dan menandakan bahwa proses fermentasi telah selesai.

D. Perancangan keseluruhan sistem

Alat fermentasi singkong memiliki tinggi $60 \mathrm{~cm}$, lebar $50 \mathrm{~cm}$ dan tinggi $60 \mathrm{~cm}$. Didalam 
inkubator masih terdapat kotak keranjang berukuran lebih kecil sebagai wadah singkong. Perancangan ini menggunakan pipa galvalum dan plat seng, penghangat ruang inkubator menggunkan jenis heater tubular. Sensor DHT11 dan MQ3 diletakkan berketan di bagian atas alat, heater berada dibagian belakang sementara loadcell berada di bagian bawah. Hasil data yang diolah oleh mikrokonroler berada di luar inkubator agar tidak mudah rusak terkena suhu yang hangat.

Berikut gambar perancangan mekanik yang akan digunakan sebagai alat fermentasi.

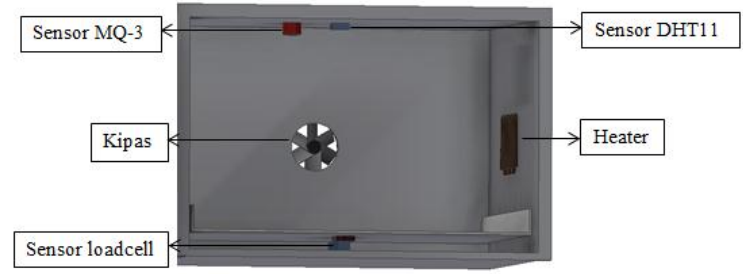

Gambar 6. perancangan sistem

Dari gambar di atas maka dapat diketahui bagianbagian yang terdapat di dalam inkubator.

1. Loadcell di bagian bawah di gunakan untuk menentukan takaran ragi yang di butuhkan

2. 2 kipas yang berada di sisi-sisi samping inkubator digunakan sebagai pendingin apabila suhu ruangan inkubator terlalu panas

3. Sisi blakang inkubator terdapat sebuah heater yang berfungsi sebagai elemen pemanas ruangan

4. Pada tutup inkubator yang tepat berdapa di sisi atas terdapat 2 buah sensor yaitu sensor DHT11 dan MQ3

5. Sisi belakang terdapat heater yangbberfungsisebagai pemanas ruang inkubator.

\section{Hasil}

A. Pengujian sensor DHT11

Pengujian sensor DHT11 dilakukan untuk mendapatkan nilai akurat dari suhu di suatu ruangan dengan membandingkan hasil pengukuran termotemeter digital . Sensor ini tidak perlu dikalibrasi karena proses kalibrasi disimpan dalam OTP program memori sehingga ketika sensor bekerja dan menghasilkan keluaran sinyal listrik maka akan secara otomatis berapa derajat suhu udara. Berikut hasil pengujian DHT11.
Tabel 1. pengujian DHT11

\begin{tabular}{|c|c|c|c|}
\hline No & $\begin{array}{c}\text { Termometer } \\
\text { digital }\end{array}$ & DHT11 & Keakuratan \\
\hline 1 & 29,8 & 29 & 97,31 \\
\hline 2 & 30,7 & 30 & $97,71 \%$ \\
\hline 3 & 31,3 & 31 & $99,04 \%$ \\
\hline 4 & 32,5 & 32 & 98,12 \\
\hline \multicolumn{3}{|c|}{ Rata-rata persentase keakuratan } & $98,04 \%$ \\
\hline
\end{tabular}

B. Pengujian sensor MQ-3

Pada pengujian sensor loadcell diperlukan roses kalibrasi untuk mendapatkan nilai keakuratan sensor. Proses kalibrasi memanfaatkan nilai ADC yang dihasilkan sensor dari 6 sampelalkohol yang telah teruji laboratorium. Proses kalibrasi menggunakan proses regresi linier karena MQ-3 yang mempunyai senstifitas yang tinggi terhadap gas alkohol serta tegangan keluaran sebanding dengan perubahan kadar gas alkohol yang dideteksi atau terletak pada suatu garis lurus[3]. Dari hasil pengujian tersebut kmudian dibandingkan dengan 6 sampel alkohol untuk mengetahui tingkat keakuratan sensor. Berkiut tabelhasil pengujian sensor MQ-3.

Tabel 2. pengujian sensor MQ-3

\begin{tabular}{|c|c|c|c|c|c|}
\hline No & $\begin{array}{c}\text { persentase } \\
\text { sebenarnya }\end{array}$ & $\begin{array}{c}\text { pembacaa } \\
\text { n ADC }\end{array}$ & $\begin{array}{c}\text { Tegang } \\
\text { an (v) }\end{array}$ & $\begin{array}{c}\text { Persentase } \\
\text { pengujian }\end{array}$ & $\begin{array}{l}\text { keakurat } \\
\text { an }\end{array}$ \\
\hline 1 & $3 \%$ & 398 & $2,19 \mathrm{v}$ & $3.19 \%$ & $93.66 \%$ \\
\hline 2 & $6.8 \%$ & 455 & $2,47 \mathrm{v}$ & $7.31 \%$ & $92.5 \%$ \\
\hline 3 & $8 \%$ & 467 & $2,575 \mathrm{v}$ & $8.53 \%$ & $93.37 \%$ \\
\hline 4 & $10 \%$ & 492 & $2,715 \mathrm{v}$ & $10.52 \%$ & $94.8 \%$ \\
\hline 5 & $13 \%$ & 536 & $2,845 \mathrm{v}$ & $12.50 \%$ & $96.15 \%$ \\
\hline 6 & $15 \%$ & 555 & $2,95 \mathrm{v}$ & $14.18 \%$ & $94.53 \%$ \\
\hline \multicolumn{6}{|c|}{ Rata-rata persentase keakuratan } \\
\hline
\end{tabular}

C. Pengujian Sensor Loadcell

Pengujian sensor loadcell sama dengan pegujian sensor MQ-3 yaitu dilakukan proses kalibrasi terlebih dahulu untuk mendapatkan nilai keakuratan sensor. Proses kalibrasi dilakukan dengan regresi linier karena nilai tegangan dari sensor loadcell sebanding dengan sampel yang digunakan. Berikut hasil pengujian sensor loadcell. 
Tabel 3. pengujian sensor loadcell

\begin{tabular}{|c|c|l|l|l|l|}
\hline & $\begin{array}{c}\text { beban } \\
\text { sebena } \\
\text { rnya } \\
\text { No }\end{array}$ & $\begin{array}{c}\text { Tegang } \\
\text { an }\end{array}$ & $\begin{array}{c}\text { pembaca } \\
\text { an ADC }\end{array}$ & $\begin{array}{l}\text { beban } \\
\text { jian } \\
(\mathrm{gr})\end{array}$ & $\begin{array}{l}\text { keakurata } \\
\text { n }\end{array}$ \\
\hline 1 & 581 & $0.48 \mathrm{v}$ & 99 & 576 & $99,13 \%$ \\
\hline 2 & 779 & $0.64 \mathrm{v}$ & 132 & 773 & $99,22 \%$ \\
\hline 3 & 904 & $0.74 \mathrm{v}$ & 153 & 898 & $99,33 \%$ \\
\hline 4 & 1143 & $0.94 \mathrm{v}$ & 193 & 1136 & $99,38 \%$ \\
\hline 5 & 1529 & $1.25 \mathrm{v}$ & 258 & 1524 & $99,67 \%$ \\
\hline
\end{tabular}

D. Pengujian Alat

Pengujian ini bertujuan untuk menerapkan metode fuzzy tsukamoto dalam pengambilan keputusan pada alat fermentasi tape yang nantinya akan dijadikan output berupa heater dan kipas sesuai dengan input data sensor.

Tabel 4. pengujian Alat

\begin{tabular}{|c|c|c|c|c|c|}
\hline tanggal & jam & suhu & alkohol & f_kipas & f_heater \\
\hline 03.07.2019 & 8:09:00 & 26 & 0 & 0 & 255 \\
\hline 03.07.2019 & 8:12:00 & 26 & 0 & 0 & 255 \\
\hline 03.07.2019 & 8:15:00 & 27 & 0 & 0 & 255 \\
\hline 03.07.2019 & 8:18:00 & 27 & 0 & 0 & 255 \\
\hline 03.07.2019 & 8:21:00 & 28 & 0 & 0 & 255 \\
\hline 03.07.2019 & 8:24:00 & 28 & 0 & 0 & 255 \\
\hline 03.07.2019 & $8: 27: 00$ & 29 & 0 & 0 & 255 \\
\hline 03.07.2019 & 8:30:00 & 29 & 0 & 0 & 255 \\
\hline 03.07.2019 & 8:33:00 & 29 & 0 & 0 & 255 \\
\hline 03.07.2019 & 8:36:00 & 30 & 0 & 0 & 141 \\
\hline 03.07.2019 & 8:39:00 & 30 & 0 & 0 & 141 \\
\hline 03.07 .2019 & 8:42:00 & 30 & 0 & 0 & 141 \\
\hline 03.07.2019 & 8:45:00 & 30 & 0 & 0 & 141 \\
\hline 03.07.2019 & 8:48:00 & 30 & 0 & 0 & 141 \\
\hline 03.07.2019 & 8:51:00 & 30 & 0 & 0 & 141 \\
\hline 03.07.2019 & 8:54:00 & 30 & 0 & 0 & 141 \\
\hline 03.07.2019 & $8: 57: 00$ & 30 & 0 & 0 & 141 \\
\hline 03.07.2019 & 9:00:00 & 30 & 0 & 0 & 141 \\
\hline 03.07.2019 & 9:03:00 & 30 & 0 & 0 & 141 \\
\hline 03.07.2019 & 9:06:00 & 30 & 0 & 0 & 141 \\
\hline 03.07.2019 & 9:09:00 & 30 & 0 & 0 & 141 \\
\hline 03.07 .2019 & 9:12:00 & 30 & 0 & 0 & 141 \\
\hline 03.07.2019 & 9:15:00 & 31 & 0 & 0 & 56 \\
\hline 03.07.2019 & 9:18:00 & 30 & 0 & 0 & 141 \\
\hline 03.07.2019 & 9:21:00 & 30 & 0 & 0 & 141 \\
\hline 03.07.2019 & 9:24:00 & 31 & 0 & 0 & 56 \\
\hline 03.07.2019 & $9: 27: 00$ & 31 & 0 & 0 & 56 \\
\hline
\end{tabular}

Di mana : f_kipas = fuzzy kipas

f_Heater = fuzzy heater pada tabel di atas kipas dan heater akan menyala sesuai dengan hasil defuzzyfikasi. Sehingga logika fuzzy dapat menetukan kecepatan kipas dan heater sesuai dengan aturan-aturan yang telah ditentukan.

\section{E.Pengujian Sistem}

Pengujian sistem dilakukan 4 kali percobaan dengan pengontrolan sensor DHT11 dan MQ-3 yang sama yaitu $32^{\circ} \mathrm{C}-36^{\circ} \mathrm{C}$ dan $5,5 \%-6,5 \%$

[4].namun dengan perlakuan yang berbeda

a. Percobaan 1

Pada percobaan pertama ragi yang diguanan persatu $\mathrm{kg}$ singkong adalah 7 gram. Hasil fermentasi yang didapatkan adalah tingkat kematangan singkong tidak merata hal ini disebabkan karena ragi yang digunakan terlalu banyak sehingga mikro organisme pada singkong tidak berkembangbiak dengan baik dan masih terdapat gumpalan-gumapalan kecil berupa ragi pada singkong.

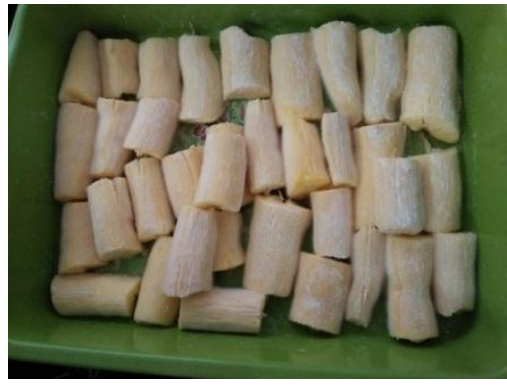

Gambar 7. percobaan 1

b. Percobaan 2

Pada percobaan kedua ragi yang dunakan lebih sedikit dari percobaan pertama yaitu 4 gram persatu $\mathrm{kg}$ singkong. Hasil fermentasi yang didapatkan adalah tingkat kematangan tape yang merata dan tape terasa manis. hal ini menandakan bahwa penggunaan ragi sudah tepat.

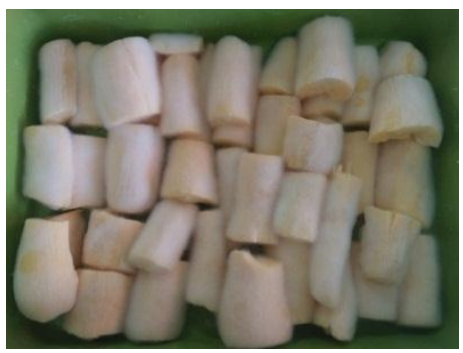

Gambar 8. percobaan 2

c. Percobaan 3

Pada percobaan ketiga ragi yang digunakan sama dengan percobaan ke 2 hanya saja singkong yang difermentasi lebih banyak yaitu 
seberat $5,13 \mathrm{~kg}$. penggunaan singkong yang lebih banyak ini bertujuan untuk melihat hasil fermentasi jika singkong yang difermentasi dalam jumlah besar. Pada percobaan letiga ini mendapatkan hasil frementasi yang sama dengan percobaan kedua hal ini menandakan bahwa banyak dan sedikitnya singkong yang difermentasi tidak berpengaruh pada alat ini.

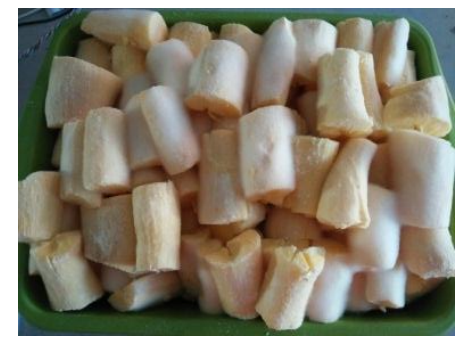

Gambar 9. percobaan 3

d. Percobaan 4

Percobaan keempat merupakan perbandingan antara fermentasi manual dan fermentasi dengan alat. Percobaan ini untuk membuktikan bahwa dengan alat fermentasi ini proses fermentasi menggunakan alat lebih cepat dari fermentasi manual.

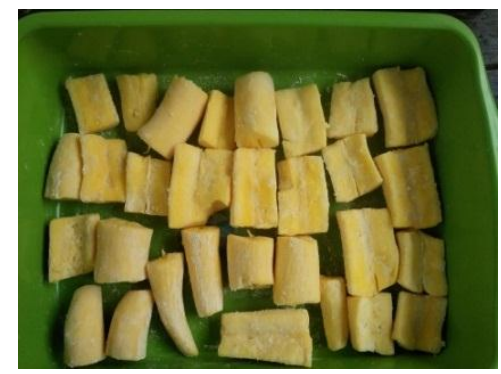

Gambar 10. fermentasi alat

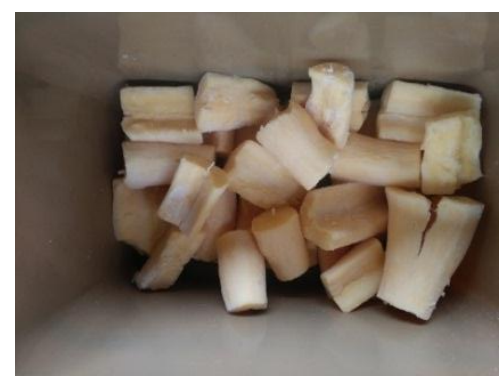

Gambar 11. fermentasi manual

F. Pengujian lama waktu fermentasi

Pada pengujian alat fermentasi secara keseluruhan ini dilakukan dengan mengukur lama waktu fermentasi. Dimana lama wakty fermentasi tidak hanya ditentukan berapa derajat celcius suhu yang digunakan pada alat tetapi juga berapa gram ragi yang
Tabel 5. Pengujian lama fermentasi

\begin{tabular}{|c|c|c|c|}
\hline $\begin{array}{c}\text { percob } \\
\text { aan }\end{array}$ & $\begin{array}{c}\text { Waktu } \\
\text { fermentasi } \\
\text { manual }\end{array}$ & $\begin{array}{c}\text { Waktu } \\
\text { fermentasi } \\
\text { dengan alat }\end{array}$ & $\begin{array}{c}\text { Persentase } \\
\text { efisiensi }\end{array}$ \\
\hline 1 & 48 jam & $\begin{array}{c}23 \text { jam 27 } \\
\text { menit }\end{array}$ & $51.14 \%$ \\
\hline 2 & 48 jam & $\begin{array}{c}16 \text { jam 13 } \\
\text { menit }\end{array}$ & $66.21 \%$ \\
\hline 3 & 48 jam & $\begin{array}{c}17 \text { jam 15 } \\
\text { menit }\end{array}$ & $63.95 \%$ \\
\hline 4 & 48 jam & $\begin{array}{c}23 \text { jam 6 } \\
\text { menit }\end{array}$ & $51.87 \%$ \\
\hline \multicolumn{3}{|c|}{ Rata-rata persentase efisiensi } & $58.29 \%$ \\
\hline
\end{tabular}

digunakan persatu kg singkong.

Dari tabel diatas dapat diketahui bahwa proses fermentasi dengan menggunakan alat lebih cepat dari fermentasi manual hingga mencapai efeisiensi 58,29\%.

\section{PENUTUP}

A. Kesimpulan

Berdasarkan hasil peranangan, implementasi sistem dan pengujian hasil dari sistem yang telah dibuatdapat ditarik beberapa kesimpulan sebagai berikut.

1. Ragi yang tepat digunakan untuk melakukan fermentasi singkong adalah 4 gram $/ \mathrm{kg}$ singkong.

2. Alat fermentasi singkong yang telah dirancang dengan tipe inkubator yang dilengkapi dengan sensor Loadcell, MQ-3 dan DHT11 ini telah sesuai dengan kebutuhan yang diperlukan untuk solusi fermentasi secara manual dikarenakan alat ini lebih efisien yaitu fermentasi hanya berlangsung kurang lebih 24 jam yang artinya meningkatkan hasil produksi tape hingga 2 kali lipat dari fermentasi manual.

3. Metode fuzzy Tsukamoto yang digunakan sebagai metode pengambilan keputusan dalam sistem telah sesuai dengan yang diharapakan. Dengan hasil rata-rata persentase eror $8,28 \%$ dan efisiensi alat sebesar 58,29\%.

B. Saran

Diharapkan pada penelitian selanjutnya menggunakan metode yang lain sehingga dapat mengurangi persentase kesalahan pada alat ini. 


\section{Daftar Pustaka}

[1] Trigan. J, Pengantar Mikrobiologi, Jakarta (ID): Departemen Pendidikan dan Kebudayaan Direktorat Jendral Perguruan Tinggi, 1988.

[2] G. Mazenda, A. A. Soebroto dan c. Dewi , "Implementasi Fuzzy Inteferensi system (FIS) Metode Tsukamoto Pada Sistem Pendukung Keputusan Penentuan Kualitas Air Sungai," vol. I, 2014.

[3] I. G. S. Merta, I. G. A. Widagda dan A. I. B. Paramarta, "Perancangan Alat Ukur Alkohol Menggunakan Sensor MQ-3 Berbasis Mikrokontroler Atmega16," vol. 18, 2017.

[4] H. Hasanah, A. Jannah dan A. G. fasha, "Pengaruh Lama Fermentasi Terhadap Kadar Alkohol Tape Singkong (Manihot utilissima Pohl).," alchemy, vol. 2, p. 68, 2013. 